\title{
Changes in Ribosomes Associated with Spore Senescence in the Bean Rust Fungus
}

\author{
By ZOHARA YANIV AND R. C. STAPLES \\ Boyce Thompson Institute, Yonkers, New York I070 I, U.S.A.
}

(Received 21 December 1973; revised 26 July 1974)

SUMMAR Y

\begin{abstract}
Studies were carried out to identify the cause of the decline in transferase activity and capacity to bind polyuridylic acid which occurs in ribosomes from germinated uredospores of the bean rust fungus, Uromyces phaseoli (Pers.) Wint., aged longer than $6 \mathrm{~h}$ on a water surface. We have shown that such ribosomes lose the capacity to respond to added transferase- 1 and that both subunits were affected by the ageing process. These changes were not accompanied by a significant alteration in the composition of the ribosome. However, deoxycholate had a greater detergent effect on ribosomes from germinated spores than from nongerminated spores as shown both by loss of capacity to polymerize amino acids and loss of protein. Ribonuclease activity did not increase during germination, but the amount found ( $\mathrm{I} \mu \mathrm{g} / \mathrm{g}$ spores) was easily detectable. It was suggested that loss of response to transferase-I was due to an alteration of ribosomal proteins of both subunits.
\end{abstract}

\section{INTRODUCTION}

Uredospores of the bean rust fungus, Uromyces phaseoli (Pers.) Wint., germinate readily on water or moist surfaces such as agar or collodion (Staples, Yaniv, Ramakrishnan \& Lipetz, 197I). The germ tubes formed are simple, vacuolated, and very long. Formation of infection structures occurs on the collodion membranes only if paraffin oil is added.

Ribosomes from the germ tubes rapidly lose the capacity to incorporate amino acids after about $6 \mathrm{~h}$ (Staples et al. 1971). If the spores are germinated on water, ribosomal responsiveness to transferase-1 (EF-I) begins to decline after $2 \mathrm{~h}$ of germination, while ribosomes from spores germinated on membranes remain fully competent (Staples, Yaniv \& Bushnell, 1972; Yaniv \& Staples, 1974). In addition, there is a reduced incorporation of leucine into protein by whole spores after germination (Staples et al. 1972), a declining rate of germ tube elongation after $6 \mathrm{~h}$ (Yaniv \& Staples, 1969), and a loss of protein content after $6 \mathrm{~h}$ (Trocha \& Daly, 1970). All of these observations point to the general onset of senescence after approximately $6 \mathrm{~h}$ of germination which can be detected as early as $2 \mathrm{~h}$ in spores germinated on water. The purpose of our study was to examine more closely the effect of senescence on ribosomes from germ tubes.

\section{METHODS}

Special chemicals. L- $\left[{ }^{14} \mathrm{C}\right]$ phenylalanine (specific activity $375 \mathrm{mCi} / \mathrm{mmol}$ ) was purchased from New England Nuclear Corp., Boston, Massachusetts, U.S.A., and yeast tRNA from General Biochemicals Corp., Chagrin Falls, Ohio, U.S.A. Polyuridylic acid (Miles Laboratories, Kankakee, Illinois, U.S.A.) had a molecular weight greater than 100000 daltons (gel filtration).

Vol 87, No. I, was issued 27 March 1975 
Spores. The procedures for collection and germination of uredospores have been described previously (Staples et al. 1972; Yaniv \& Staples, I969). Spores were either hydrated (nongerminated) or germinated $20 \mathrm{~h}$ on water (germinated).

Ribosomes. Procedures for the preparation of ribosomes, post-ribosomal supernatant solutions, and $\left[{ }^{14} \mathrm{C}\right]$ phenylalanyl-tRNA were described previously (Yaniv \& Staples, 1969). Briefly, I $\mathrm{g}$ of uredospores was ground in a ball mill for I 5 min at $4{ }^{\circ} \mathrm{C}$ with I $5 \mathrm{ml}$ of a buffer ( $\mathrm{pH} 7.5$ ) composed of $0.45 \mathrm{M}$-sucrose, $50 \mathrm{~mm}$-tris [tris(hydroxymethyl)aminomethane], $5 \mathrm{~mm}-\mathrm{MgCl}_{2}$, and $5 \mathrm{~mm}-2$-mercaptoethanol. The homogenate was centrifuged for $15 \mathrm{~min}$ at $20000 \mathrm{~g}$ and the supernatant solution $\left(\mathrm{S}_{3} \mathrm{O}\right)$ was stored at $-20{ }^{\circ} \mathrm{C}$ for periods up to three weeks. Ribosomes were obtained from the $\mathrm{S}_{30}$ by centrifuging for $60 \mathrm{~min}$ at $15 \mathrm{I} 000 \mathrm{~g}$. The pellet was resuspended in TKM buffer $(\mathrm{pH} \mathrm{7.5)}$ composed of $50 \mathrm{mM}$-tris, $15 \mathrm{mM}-\mathrm{KCl}$,

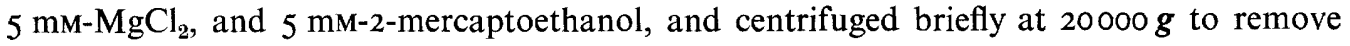
aggregates.

When ribosomes washed with deoxycholate were desired, ribosome suspensions were made to $0.25 \%$ with sodium deoxycholate. Ribosomes were then recovered by centrifuging for $60 \mathrm{~min}$ at $\mathrm{I} 5 \mathrm{I} 000 \mathrm{~g}$ and resuspended in TKM buffer.

The upper half of the postribosomal supernatant solution from nongerminated spores was passed through a $2 \times 20 \mathrm{~cm}$ column of Sephadex G 25 equilibrated in TKM buffer. Protein in the void volume was precipitated with ammonium sulphate, then redissolved in TKM buffer. After storage in liquid nitrogen for one week to destroy EF-2, the solution was used as the source of EF-I (Yaniv \& Staples, I97I).

For subunits, ribosomes were dissociated in 10 to $30 \%$ sucrose gradients (Brakke \& Van Pelt, 1970) containing 0.5 M-KCl in TKM buffer (App, Bulis \& McCarthy, 197I). After centrifuging for $3 \mathrm{~h}$ at $40000 \mathrm{rev} . / \mathrm{min}$ in a Spinco SW $4 \mathrm{I}$ rotor (Beckman Instruments Incorporated, Palo Alto, California, U.S.A.), the gradients were fractionated with an ISCO Model D fractionator (Instrumentation Specialties Co., Lincoln, Nebraska, U.S.A.) and the subunits collected by centrifuging at $\mathrm{I} 5 \mathrm{I} 000 \mathrm{~g}$ for $3 \mathrm{~h}$. Alternatively, subunits were prepared equally well using 10 to $30 \%$ sucrose gradients prepared in TKM buffer from which magnesium was omitted.

For assay of protein and RNA content, ribosomes were precipitated with $5 \%$ trichloroacetic acid, placed in a boiling water bath for $20 \mathrm{~min}$, cooled, and centrifuged at 4000 rev./min for Io min. The RNA content of the supernatant solution was estimated spectrophotometrically $\left(50 \mu \mathrm{g} / E_{260}\right)$ or by the orcinol procedure with yeast RNA as a standard (Mejbaum, I953). Protein in the pellet was estimated by the procedure of Lowry, Rosebrough, Farr \& Randall (I95I) using bovine serum albumin as a standard.

To study the protein composition, ribosomes were extracted by the acetic acid procedure of Hardy, Kurland, Voynow \& Mora (1969). The proteins were analysed by electrophoresis on polyacrylamide gels according to the procedure of Reisfeld, Lewis \& Williams (1962) as modified by Leboy, Cox \& Flaks (1964). The bottom gel $(55 \times 6 \mathrm{~mm})$ contained $10 \%(\mathrm{w} / \mathrm{v})$ acrylamide and $0.15 \%(\mathrm{w} / \mathrm{v})$ methylenebisacrylamide. The upper gel $(0.3 \mathrm{ml})$ contained $2.5 \%$ acrylamide and $0.625 \%$ methylenebisacrylamide. Up to $0.2 \mathrm{ml}$ of protein solution was used mixed with acetic acid-urea buffer. Gels were run at $3 \mathrm{~mA} /$ tube for $4 \mathrm{~h}$, the gels washed overnight in $12.5 \%$ trichloroacetic acid, and stained with Coomassie blue (Macko \& Stegemann, 1969). The gels were scanned with a Joyce-Loebl microdensitometer (Tech-Ops Co., Burlington, Massachusetts, U.S.A.).

Assay for EF-I. Ribosomes were assayed for polyuridylic acid-directed binding and EF-I dependent binding of phenylalanyl-tRNA using the modification of the procedures of Nirenberg \& Leder (I964) described previously (Yaniv \& Staples, I969; 197I). The reaction 
mixture $(0.5 \mathrm{ml})$ contained: $6 \mathrm{mmol}$ tris- $\mathrm{HCl}(\mathrm{pH} 7.8)$, $5 \mathrm{mmol} \mathrm{KCl}, 4 \mathrm{mmol}$ magnesium acetate, $40 \mu \mathrm{g}$ polyuridylic acid, $5 \mathrm{mmol} 2$-mercaptoethanol, $38 \mu \mathrm{mol} \mathrm{GTP}, 100 \mu \mathrm{g}$ ribosomes or subunits, $100 \mu \mathrm{g}\left[{ }^{14} \mathrm{C}\right]$ phenylalanyl-tRNA (I0000 c.p.m.), and the indicated amounts of aged EF-I purified from nongerminated spores through ammonium sulphate fractionation. After 20 min incubation at $30^{\circ} \mathrm{C}, 2 \mathrm{ml}$ of cold TKM buffer was added. Binding was measured as described previously (Yaniv \& Staples, 1969) and radioactivity assayed by liquid scintillation procedures.

Activity of ribonuclease. Ribonuclease activity was determined by using the assay described by Kalnitsky, Hummel \& Dierks (1959) wherein the hydrolysis of RNA at $\mathrm{pH} 5^{\circ} \mathrm{O}$ is determined by measuring the amount of acid-soluble oligonucleotide liberated at $\mathrm{O} \cdot \mathrm{I}$ Macetate buffer. A second procedure also used was based upon the release of soluble oligonucleotides following the digestion of yeast RNA at $\mathrm{pH}_{7.5}$ in $0.2 \mathrm{M}$-tris buffer (Egami, Takahashi \& Uchida, I964).

Analysis of RNA. RNA was extracted from spores as described by Lovett \& Haselby (I97I) except that spores were ground for I $5 \mathrm{~min}$ in a ball mill. One gram spores was milled in $15 \mathrm{ml}$ solution which consisted of $7.5 \mathrm{ml}$ of TIPS [ $100 \mathrm{ml} 0.01 \mathrm{M}$-tris(hydroxymethyl)aminomethane buffer $\mathrm{pH} 7 \cdot 6$, I g tri-isopropylnaphthalenesulphonic acid, $6 \mathrm{~g}$ 4-aminosalicylic acid, and $0.37 \mathrm{~g} \mathrm{KCl}$, and $7.5 \mathrm{ml}$ of phenol-cresol solution $(50 \mathrm{ml}$ redistilled phenol, $7 \mathrm{ml} p$-cresol, $20 \mathrm{ml}$ water, and $50 \mathrm{mg} 8$-hydroxyquinoline). Spores were milled in a cold room at $4{ }^{\circ} \mathrm{C}$. The phases were separated by centrifuging and the RNA recovered as described by Lovett \& Haselby (197I).

The RNA mixture was resolved by electrophoresis on $2.4 \%$ polyacrylamide gels as described by Loening (1967), while molecular weights were estimated on the gels following Loening (I969). Ribosomal RNA from Escherichia coli was used as a standard.

\section{RESULTS \\ Activity of $E F-\mathrm{I}$}

The decline in ribosomal EF-I activity is one of the important biochemical changes that occurs during the germination of bean rust uredospores (Staples et al. 197I). To illustrate this, typical assays of ribosomes for polyuridylic acid-directed binding and EF-I dependent binding of phenylalanyl-tRNA are summarized in Fig. I. Ribosomes from germinated spores had one-fifth the activity of ribosomes from nongerminated spores even when tested with 25 to $50 \mu \mathrm{g}$ of the transferase factor. This shows in a different way the lack of responsiveness of ribosomes from germinated spores even in the presence of high enzyme concentration.

Mixing experiments were performed to eliminate the possibility that an inhibitor might be responsible for the decreased activity of the ribosomes from germinated spores. It can be seen in Table $\mathrm{r}$ that the addition of rather large amounts of the virtually inactive ribosomes from germinated spores did not alter the activity of ribosomes from nongerminated spores.

\section{Activity of ribosomal subunits}

Ribosomes from germinated spores were dissociated in the presence of $\mathrm{KCl}$, and their ability to reassociate upon dialysis with TKM buffer was assayed by centrifugation on sucrose gradients (Fig. 2). The density gradient profiles of the senescent ribosomes after reassociation appeared to be normal.

Nevertheless, it was considered that germination of uredospores for $20 \mathrm{~h}$ altered one or both of the subunits in such a way that the ribosome no longer responded to EF-I, since the 


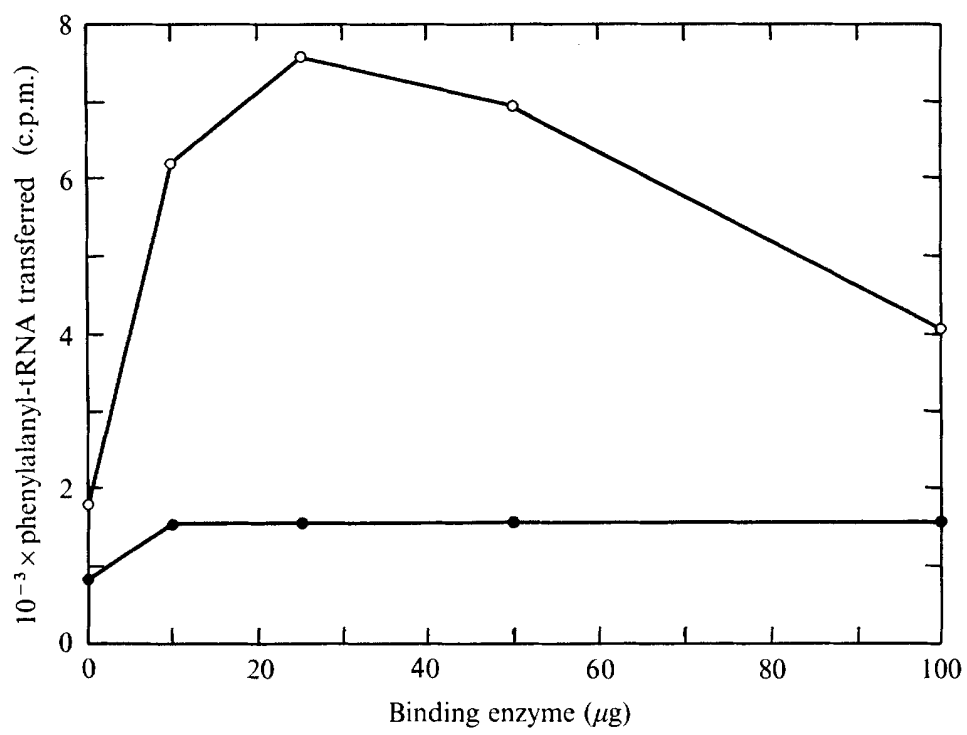

Fig. I. EF-I dependent binding and polyuridylic acid-directed binding of phenylalanyl-tRNA by ribosomes from spores germinated $20 \mathrm{~h}(\mathrm{O})$ and nongerminated $(\mathrm{O})$ uredospores.

Table I. The lack of inhibitory effect of added ribosomes from germinated spores on the capacity of ribosomes for nongerminated spores to bind phenylalanyl-tRNA

The reaction mixture is given in Methods.

Ribosomes $(\mu \mathrm{g})$ from spores which were

$\begin{array}{ccr}\text { Nongerminated } & \begin{array}{c}\text { Germinated } \\ (20 \mathrm{~h})\end{array} & \begin{array}{r}\text { Ribosome act } \\ \text { (c.p.m. }\end{array} \\ - & - & 543 \\ 100 & - & 8480 \\ - & 520 & 547 \\ 100 & 520 & 8660\end{array}$

activity of ribosomes from germinated spores was so very low (Fig. 1). To test this, ribosomal hybrids were made by mixing subunits from germinated and nongerminated spores. After dialysis against TKM buffer to allow reassociation, as shown by analysis on sucrose gradients similar to those in Fig. 2, the hybrid ribosomes were tested for capacity to bind phenylalanyltRNA in the assay for activity of EF-I. The activities of reassociated hybrid ribosomes were compared with those from germinated and nongerminated spores, and it was found that after reassociation, ribosomes from spores germinated $20 \mathrm{~h}$ were $6 \%$ as active as ribosomes from nongerminated spores, while hybrid ribosomes were $26 \%$ as active.

Theoretically, if spore germination altered both subunits, addition of damaged subunits to a suspension of active subunits should yield a mixture of ribosome hybrids having a transferase activity of $25 \%$ of that for undamaged ribosomes, assuming a completely random reassociation. In contrast, the expected activity would have been $50 \%$ if only one subunit had been damaged, and $100 \%$ if neither subunit was damaged. The data, therefore, indicate that the process of ageing in germinated uredospores damages both subunits.

To test this conclusion, subunits were prepared using ribosomes from nongerminated spores and spores germinated for $20 \mathrm{~h}$. The ribosomes were separated into subunits by 


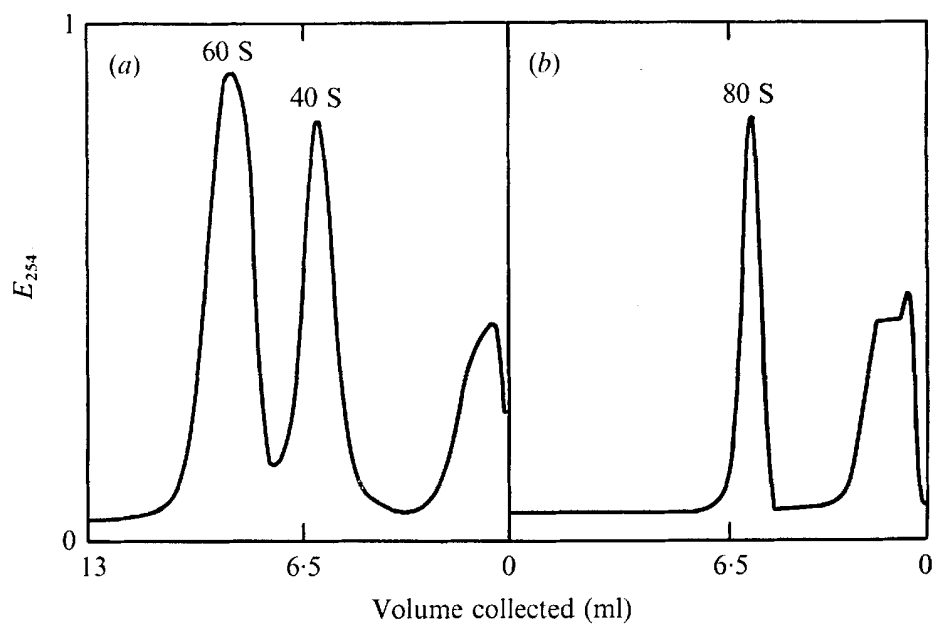

Fig. 2. The capacity of ribosomes from germinated spores to reassociate after dissociation in $\mathrm{KCl}$ gradients. Ribosomes $\left(6.2 E_{260}\right)$ were layered on to 15 to $30 \%$ sucrose gradients containing $0.5 \mathrm{M}$ $\mathrm{KCl}$ in TKM buffer. Gradients were centrifuged for $3 \mathrm{~h}$ at $40000 \mathrm{rev}$. $/ \mathrm{min}$ in a Spinco SW $4 \mathrm{I}$ rotor, gradients fractionated, subunits pooled and collected by centrifuging for $3 \mathrm{~h}$ at $\mathrm{I} 5 \mathrm{I} 000 \mathrm{~g}$ in a Spinco 65 rotor. Subunits were resuspended in TKM, and $2 \cdot 1 E_{260}$ units layered on to a 5 to $30 \%$ sucrose gradient in TKM buffer and centrifuged for $75 \mathrm{~min}$ at $40000 \mathrm{rev} . / \mathrm{min}$ in a Spinco SW 4I rotor. (a) Profile of subunits; $(b)$ profile of ribosomes after reassociation of subunits.

Table 2. Polyuridylic acid-directed EF-I activity of ribosome couples formed from isolated subunits obtained from germinated and nongerminated spores

Source of subunits

\begin{tabular}{cccccc}
\multicolumn{2}{c}{} & \multicolumn{2}{c}{ Germinated spores } \\
$40 \mathrm{~S}$ & $60 \mathrm{~S}$ & $\overbrace{40 \mathrm{~S}}$ & $60 \mathrm{~S}$ & C.p.m. $/ E_{260}$ & $\%$ \\
+ & + & - & - & 1236 & 100 \\
+ & - & - & + & 52 & $4 \cdot 2$ \\
- & + & + & - & 118 & $9 \cdot 5$ \\
- & - & + & + & 10 & 0.8
\end{tabular}

centrifuging in sucrose gradients devoid of magnesium, and the subunits collected. The various species of subunits were added in equal amounts to the transferase reaction mixture so that the subunit couples could be examined separately. The couples were then analysed for transferase (EF-r) activity and for reassociation by sucrose gradient analyses. The data in Table 2 show again that ribosome couples which were composed of subunits from germinated spores or were hybrid ribosomes were nearly inactive, while those composed of subunits from nongerminated spores vigorously bound phenylalanyl-tRNA.

\section{Ribonuclease activity}

Ribonuclease activity was assayed in extracts of uredospores to determine if any change in the activity of these enzymes during germination could contribute to the decline in ribosomal response to EF-I. There was no change in activity during germination ( $\mathrm{I} \cdot \mathrm{O}$ to $\mathrm{I} \cdot 2 \mu \mathrm{g} / \mathrm{g}$ spore), despite the use of two sensitive assays. 


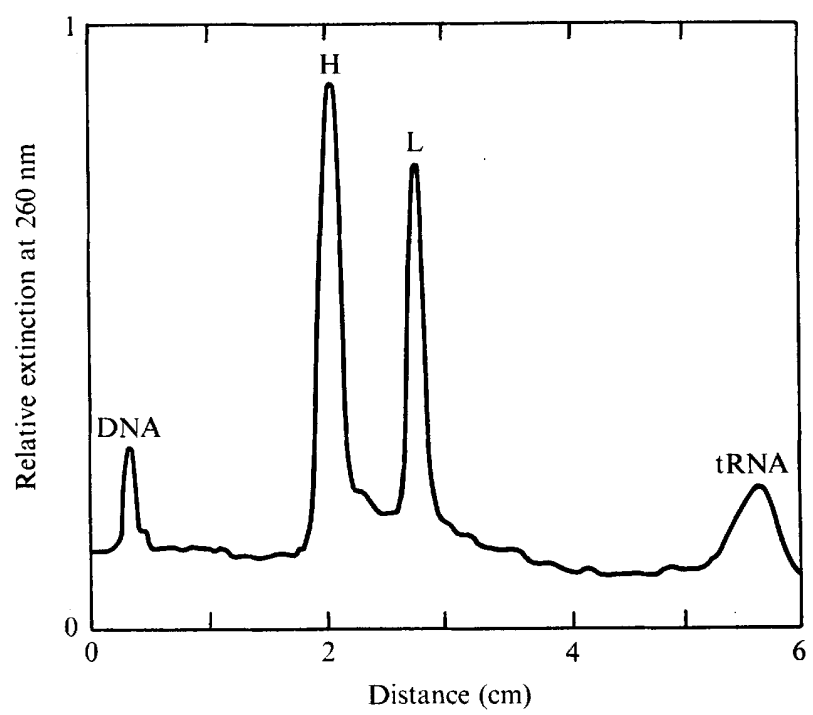

Fig. 3. Polyacrylamide gel electrophoresis of RNA from bean rust uredospores germinated $20 \mathrm{~h}$ on water. RNA (IO $\mu \mathrm{g}$ ) was applied to the $2.4 \%$ gel and electrophoresis was carried out for $\mathrm{I} \cdot 75 \mathrm{~h}$ at $5 \mathrm{~mA} /$ gel. The peak labelled DNA disappeared when the RNA was treated with DNase. Peaks labelled $\mathrm{H}$ and $\mathrm{L}$ correspond to ribosomal RNA having molecular weights of $1 \cdot 3 \times 10^{6}$ and $0.7 \times 10^{6}$ daltons, respectively. The peak labelled tRNA was not identified rigorously.

\section{Table 3. Protein and RNA content of ribosomes from bean rust uredospores}

Ribosomes were washed with deoxycholate and purified on sucrose density gradients. Protein was determined by the Lowry procedure (Lowry et al. $195 \mathrm{I}$ ) with an error of $\pm 7 \%$. RNA was determined both by the Orcinol procedure (Mejbaum, 1963) with an error of $\pm 9 \%$ and by extinction at $260 \mathrm{~nm}$ $\left(50 \mu \mathrm{g} / E_{260}\right)$. Agreement of the two procedures was within $4 \%$.

$\begin{array}{cccc}\begin{array}{c}\text { Germination } \\ \text { time (h) }\end{array} & \begin{array}{c}\text { Protein } \\ (\%)\end{array} & \begin{array}{c}\text { RNA } \\ (\%)\end{array} & \text { Protein:RNA } \\ 0 & 32 \cdot 5 & 67.5 & 0.48 \\ 20 & \mathrm{I} \cdot \mathrm{I} & 8 \mathrm{I} \cdot 9 & 0.22\end{array}$

\section{Protein and RNA composition of ribosomes}

The reduced EF-I activity of ribosomes and apparent damage to both subunits during the ageing process suggested that the protein and/or RNA composition of the ribosomal subunits may have been altered during germination. An extensive study of ribosomal RNA by analysis on polyacrylamide gels failed to reveal signs of RNA degradation in ribosomes from germinated spores. As shown in Fig. 3, resolution of ribosomal RNA from an RNA extract of germinated spores was excellent and there did not appear to be evidence of degradation or presence of aggregation artifacts (Lovett \& Leaver, 1969). The estimated molecular weights of the ribosomal RNAs were $0.72 \times 10^{6}$ and $1 \cdot 30 \times 10^{6}$ daltons, respectively; the same values were obtained for ribosomal RNA from nongerminated spores.

Ribosomes purified by density gradient centrifugation were examined for their relative contents of protein and RNA. The amount of ribosomes recovered from the gradients declined from $2.2 \mathrm{mg} / \mathrm{g}$ nongerminated spores to $0.6 \mathrm{mg} / \mathrm{g}$ after germination, in agreement with previous results (Staples \& Yaniv, 1973). The ratio of RNA to protein of such gradient-purified ribosomes remained at 0.48 regardless of the stage of germination, in agreement with the fact that the buoyant densities of the ribosomes also do not change 


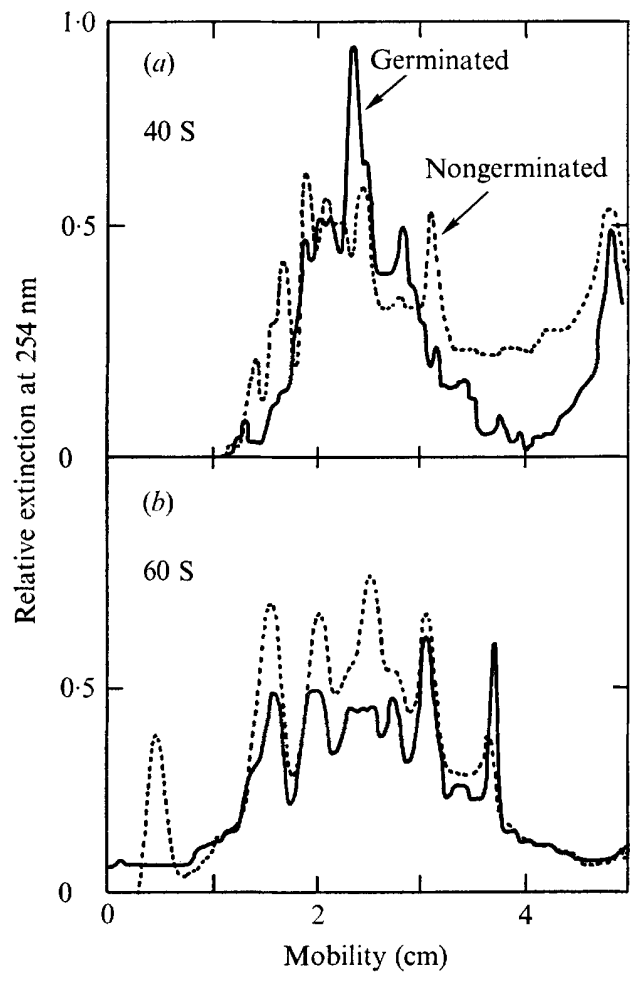

Fig. 4. Extinction profiles of proteins from ribosomal subunits analysed on polyacrylamide gels (Leboy et al. 1964). Gels were run 4 h at $3 \mathrm{~mA} / \mathrm{gel}$, stained with Coomassie blue (Macko \& Stegemann, 1969) and scanned at $620 \mathrm{~nm}$ with a Chromoscan scanner. (a) Small $40 \mathrm{~S}$ subunits; (b) large $60 \mathrm{~S}$ subunits. Spores germinated $20 \mathrm{~h},-\ldots$; nongerminated spores, - - - -.

(Staples et al. I972). However, if the ribosomes were washed with $0.25 \%$ deoxycholate, the ratio of protein to RNA decreased from 0.48 for ribosomes from nongerminated spores to 0.22 when the spores were germinated for $20 \mathrm{~h}$ (Table 3 ).

The protein composition of gradient-purified ribosomal subunits was also examined by electrophoresis on polyacrylamide gels (Fig. 4). This showed that specific ribosomal proteins were lost after the spores were germinated, while one band of protein from each subunit appeared to increase.

\section{DISCUSSION}

The loss of capacity of ribosomes from germinated spores to bind phenylalanyl-tRNA even when EF-I was added in large amounts (Fig. I) does not appear to be due to ribosomal degradation. We have previously shown that the amount of ribosomes did not decline during spore germination (Staples et al. I97I), and that the sedimentation constants and buoyant densities of the ribosomes were also unchanged (Staples et al. 1972). These data are in agreement with our report now that the ratio of protein to RNA of ribosomes does not decline during germination. The buoyant density value should have increased if the protein content had decreased (Hamilton, Pavlovec \& Petermann, 197I).

In view of the fact that deoxycholate can more easily remove protein from ribosomes of aged spores (Table 3), we suggest that the protein of the ribosomes becomes more loosely attached to the ribosomes during the late stages of germination, and that this changed 
association of protein results in a ribosome that is less responsive to added EF-I. Previously we showed that deoxycholate treatment seriously reduced the transferase activities of ribosomes from germinated spores, and that the longer germination proceeded, the greater was the detergent effect (Staples et al. 197I). We also showed that ribosomes from aged spores lost their capacity to bind polyuridylic acid (Staples et al. 1972). Our present results show that both subunits of ribosomes from aged spores are damaged. Studies of proteins from subunits by gel electrophoresis (Fig. 4) indicate that this is the result of changes in the protein component of the ribosomes.

Similar reports on changes in ribosomal activity during senescence in plant organs have been described before (Srivastava \& Arglebe, 1967; Obrig \& Gottlieb, I970; Lin, Travis, Chia \& Key, I973), although the location of the defect in the protein synthetic system which caused the decline in ribosomal activity was not the same. In ageing mycelia of Rhizoctonia solani, the decrease in activity was found to be due in part to a decrease in tRNA synthetase activity and in part to an accelerated degradation of soluble phenylalanyl-tRNA by the ribosomes of the older cells (Obrig \& Gottlieb, I970). The latter, according to the authors, could be due to the presence of nucleases in ribosomal preparations of older cells. No differences were found in magnesium optimum between ribosomes from young and aged mycelia. In contrast, the decrease in protein synthetic activity of ribosomes during maturation of pea roots and ageing corn seedlings was accompanied by a shift in requirement for magnesium from $16 \mathrm{~mm}$ - to $22 \mathrm{~mm}$-magnesium (Lin et al. 1973). A shift in magnesium optimum was not found for aged rust ribosomes (Staples et al. 1972).

As was shown here for the rust ribosomes, the decrease in ribosomal activity of corn leaves was correlated with differences in ribosomal proteins as revealed by gel electrophoresis (Lin et al. 1973). These authors found that ageing was accompanied by the loss of specific proteins. They also found that the reduced activity of the aged ribosomes was not due to the presence of inhibitors or to the activity of ribonuclease, and the reduced activity of aged rust ribosomes also does not appear to involve the activities of inhibitors (Table I) or nucleases. In contrast, Srivastava \& Arglebe (1967) reported that a gross degradation of ribosomes occurred during ageing of barley leaves.

All our present studies were dependent on polyuridylic acid, an artificial messenger RNA, and the relevance of interpretations from these data to in vivo protein synthesis is open to question. However, the decline in leucine incorporation into protein that occurs after $6 \mathrm{~h}$ and the loss of capacity of ribosomes to incorporate amino acids when dependent on endogenous messenger RNA (Staples et al. 197I) separately suggest that the ribosomal changes reported here are a natural occurrence. In addition, Trocha \& Daly (1970) have found that proteins accumulate in the germ tubes during $\mathrm{I} \cdot 5$ to $3 \mathrm{~h}$ of germination, after which the protein content declines. We believe, therefore, that the changes in the ribosomal proteins that we have been studying are directly relevant to the changes in protein synthesis which occur in the germinating spore.

This work was supported in part by a grant from the U.S. National Science Foundation (GB 4I 295). This paper is Part 4 of a series entitled 'Spore germination and ribosomal activity in the rust fungi.' 


\section{REFERENCES}

APP, A. A., Bulis, M. G. \& McCarthy, W. J. (1971). Dissociation of ribosomes and seed germination. Plant Physiology 47, 8I-86.

Brakke, M. K. \& VAN Pelt, N. (1970). Linear-log sucrose gradients for estimating sedimentation coefficients of plant viruses and nucleic acids. Analytical Biochemistry 38, 56-64.

Egami, F., Takahashi, K. \& Uchida, T. (I964). Ribonucleases in Taka-Diastase: Properties, chemical nature, and applications. Progress in Nucleic Acid Research and Molecular Biology 3, 59-10I.

hamilton, M. G., Pavlovec, A. \& Petermann, M. L. (1971). Molecular weight, buoyant density, and composition of active subunits of rat liver ribosomes. Biochemistry Io, 3424-3427.

Hardy, S. J. S., Kurland, C. G., Voynow, P. \& Mora, G. (1969). The ribosomal proteins of Escherichia coli. I. Purification of the $30 \mathrm{~S}$ ribosomal proteins. Biochemistry 8, 2897-2905.

Kalnitsky, G., Hummel, J. P. \& Dierks, C. (1959). Some factors which affect the enzymatic digestion of ribonucleic acid. Journal of Biological Chemistry 234, I512-1516.

Leboy, P. S., Cox, E. C. \& Flaks, J. G. (1964). The chromosomal site specifying a ribosomal protein in Escherichia coli. Proceedings of the National Academy of Sciences of the United States of America 52, 1367-1374.

Lin, C. Y., Travis, R. L., Chia, L. S. Y. \& Key, J. L. (I973). Protein synthesis by 80 S ribosomes during plant development. Phytochemistry 12, 515-522.

LoeNING, U. E. (1967). The fractionation of high-molecular-weight ribonucleic acid by polyacrylamide-gel electrophoresis. Biochemical Journal ro2, $25 \mathrm{I}-257$.

LoENING, U. E. (1969). The determination of the molecular weight of ribonucleic acid by polyacrylamide-gel electrophoresis. Biochemical Journal Ir3, I3 $1-138$.

LovetT, J. S. \& HASELBY, J. A. (197I). Molecular weights of the ribosomal ribonucleic acid of fungi. Archiv für Mikrobiologie 80, 191-204.

LOVETT, J. S. \& LEAVER, C. J. (1969). High-molecular-weight artifacts in RNA extracted from Blastocladiella at elevated temperatures. Biochimica et biophysica acta 195, 319-327.

Lowry, O. H., Rosebrough, N. J., Farr, A. L. \& Randall, R. J. (I95I). Protein measurement with the Folin phenol reagent. Journal of Biological Chemistry I93, 265-275.

Macko, V. \& StegemanN, H. (1969). Mapping of potato proteins by combined electrofocusing and electrophoresis. Identification of varieties. Zeitschrift für physiologische Chemie 350, 917-9I9.

Mejbaum, W. (1953). Über die bestimmung kleiner Pentosenmengen, insbesondere in Derivaten der Adenylsaüre. Zeitschrift für physiologische Chemie 258, I 17-1 20.

NiRENBERG, M. \& LeDer, P. (1964). RNA codewords and protein synthesis. The effect of trinucleotides upon the binding of sRNA to ribosomes. Science, New York 145, I399-I 107.

OвRiG, T. G. \& GotTLieB, D. (1970). In vitro protein synthesis and aging in Rhizoctonia solani. Journal of Bacteriology Iо1, 755-762.

Reisfeld, R. A., LeWIS, U. J. \& Williams, D. E. (1962). Disk electrophoresis of basic proteins and peptides on polyacrylamide gels. Nature, London 195, 28I-283.

SrivastaVA, B. I. S. \& Arglebe, C. (1967). Studies on ribosomes from barley leaves. Changes during senescence. Plant Physiology 42, I497-I 503.

StaPLes, R. C. \& Yaniv, Z. (1973). Spore germination and ribosomal activity in the rust fungi. II. Variable properties of ribosomes in the Uredinales. Physiological Plant Pathology 3, 137-145.

Staples, R. C., YANiv, Z. \& BUShNell, W. R. (1972). Spore germination and ribosomal activity in the rust fungi. I. Comparison of a bean rust fungus and a culturable wheat rust fungus. Physiological Plant Pathology 2, 27-35.

Staples, R. C., Yaniv, Z., Ramakrishnan, L. \& Lipetz, J. (I97I). Properties of ribosomes from germinating uredospores. In Morphological and Biochemical Events in Plant-Parasite Interaction, pp. 59-90. Edited by S. Akai \& S. Ouchi. Tokyo: The Phytopathological Society of Japan.

TROCHA, P. \& DalY, J. M. (1970). Protein and ribonucleic acid synthesis during germination of uredospores. Plant Physiology 46, 520-526.

Yaniv, Z. \& STAPLES, R. C. (1969). Transfer activity of ribosomes from germinating uredospores. Contributions from Boyce Thompson Institute 24, $157-163$.

YANIV, Z. \& STAPLES, R. C. (I97I). The purification and properties of the aminoacyl-tRNA binding enzyme from bean rust uredospores. Biochimica et biophysica acta 232, 717-725.

Yaniv, Z. \& Staples, R. C. (1974). Ribosomal activity in uredospores germinated on membranes. Phytopathology 64, IIII-III4. 